\title{
Theoretical Study of the High-Latitude Ionosphere's Response to Multicell Convection Patterns
}

\author{
J. J. SOJKA AND R. W. SCHUNK
}

Center for Atmospheric and Space Sciences, Utah State University, Logan

\begin{abstract}
It is well known that convection electric fields have an important effect on the ionosphere at high latitudes and that a quantitative understanding of their effect requires a knowledge of the plasma convection pattern. When the interplanetary magnetic field (IMF) is southward, plasma convection at $F$ region altitudes displays a two-cell pattern with antisunward flow over the polar cap and return flow at lower latitudes. However, when the IMF is northward, multiple convection cells can exist, with both sunward flow and auroral precipitation (theta aurora) in the polar cap. The characteristic ionospheric signatures associated with multicell convection patterns were studied with the aid of a three-dimensional time-dependent ionospheric model. Two-, three-, and four-cell patterns were considered and the ionosphere's response was calculated for the same cross-tail potential and for solar maximum and winter conditions in the northern hemisphere. As expected, there are major distinguishing ionospheric features associated with the different convection patterns, particularly in the polar cap. For two-cell convection the antisunward flow of plasma from the dayside into the polar cap acts to maintain the densities in this region in winter. For four-cell convection, on the other hand, the two additional convection cells in the polar cap are in darkness most of the time, and the resulting $\mathrm{O}^{+}$decay acts to produce twin polar holes that are separated by a sun-aligned ridge of enhanced ionization due to theta aurora precipitation. For three-cell convection, only one polar hole forms in the total electron density, but in contrast to the four-cell case, an additional $\mathrm{O}^{+}$depletion region develops near noon owing to large electric fields causing an increased $\mathrm{O}^{+}+\mathrm{N}_{2}$ loss rate. These general distinguishing features do not display a marked universal time variation in winter.
\end{abstract}

\section{INTRODUCTION}

During the last decade, a major effort has been devoted to studying the effect that magnetospheric electric fields and particle precipitation have on the high-latitude ionosphere and neutral atmosphere. Very early, it became apparent that a quantitative understanding of the effect of these magnetospheric processes could not be obtained without a knowledge of the "global" plasma convection and particle precipitation patterns. Experimentally, information on the plasma convection pattern and associated electric fields has been obtained by a variety of techniques, including satellite and rocket-borne probes [Heppner, 1977; Maynard, 1974; Kelleyet al., 1975; Heelis et al., 1976], balloon-borne probes [Mozer and Lucht, 1974], observations of the drift of clouds of ionized barium [Haerendel et al., 1967], incoherent scatter observations of the drift of the $F$ region plasma [Evans et al., 1980; Foster et al., 1981], coherent scatter observations of the drift of $E$ region irregularities [Greenwald et al., 1978], and deductions based on the direction of geomagnetic disturbances [Maezawa, 1976]. Information on auroral particle precipitation derived from satellite-borne particle detectors [Burch et al., 1979; Frank et al., 1986] as well as from both ground-based and satellite optical instrumentation [Eather and Akasofu, 1969; Akasofu, 1976; Hardy et al., 1982; Frank et al., 1982].

Most of the measurement techniques listed above provide information on only a limited spatial region at any instant of time, requiring that the overall plasma convection and particle precipitation patterns be synthesized by combining observations made at a variety of places and times. Since individual measurements have shown the plasma convection and particle precipitation patterns to be both structured and highly variable, the synthesis of measurements made at different places and times leads to "average" rather than "instantaneous" patterns.

\footnotetext{
Copyright 1987 by the American Geophysical Union.

Paper number 6A8819.

0148-0227/87/006A-8819\$05.00
}

Nevertheless, this approach has led to a significant improvement in our understanding of magnetospheric processes and how they vary with $K p$ and the interplanetary magnetic field (IMF).

When the IMF $B_{z}$ component is southward, the average convection patterns display a two-cell structure with antisunward flow over the polar cap and return flow at lower latitudes. The size of the dawn and dusk convection cells depends on the sign of the $B_{y}$ component of the IMF, and at times, a dayside throat and a Harang discontinuity are important features of the twocell convection pattern. These convection characteristics are reflected, to varying degrees, in several empirical models that have been developed over the years [Heppner, 1972, 1977; Volland, 1975, 1978; Heelis et al., 1982; Foster, 1983; Heelis, 1984; Sojka et al., 1986]. Likewise, for southward IMF the average characteristics of the auroral oval have been identified and are adequately represented by empirical models [Wallace and Budzinski, 1981; Spiro et al., 1982; Foster et al., 1986].

When the IMF $B_{z}$ component is northward, the plasma convection and particle precipitation patterns are more complex than for southward $\boldsymbol{B}_{z}$. Maezawa [1976] interpreted groundbased magnetograms in terms of a current system that would be consistent with sunward plasma convection in the polar cap for northward IMF. This interpretation was supported by electric field measurements from satellites [Burke et al., 1979, 1982; Reiff, 1982; Frank et al., 1986]. In particular, Burke et al. [1979] suggested that a four-cell convection pattern can exist during periods when the IMF is northward, in contrast to the wellknown two-cell pattern that occurs during southward IMF. Further evidence of four-cell convection derives from measurements of the northward $B_{z}(\mathrm{NBZ})$ current system associated with such a pattern [Iijima et al., 1984], as well as from the observations of sunward flow of the thermosphere in the polar cap [Killeen et al., 1985], which is opposite to the direction expected for solar-driven flow. The sunward flow of the thermosphere at $F$ region altitudes was interpreted to be driven by sunward convection of the ionosphere. 

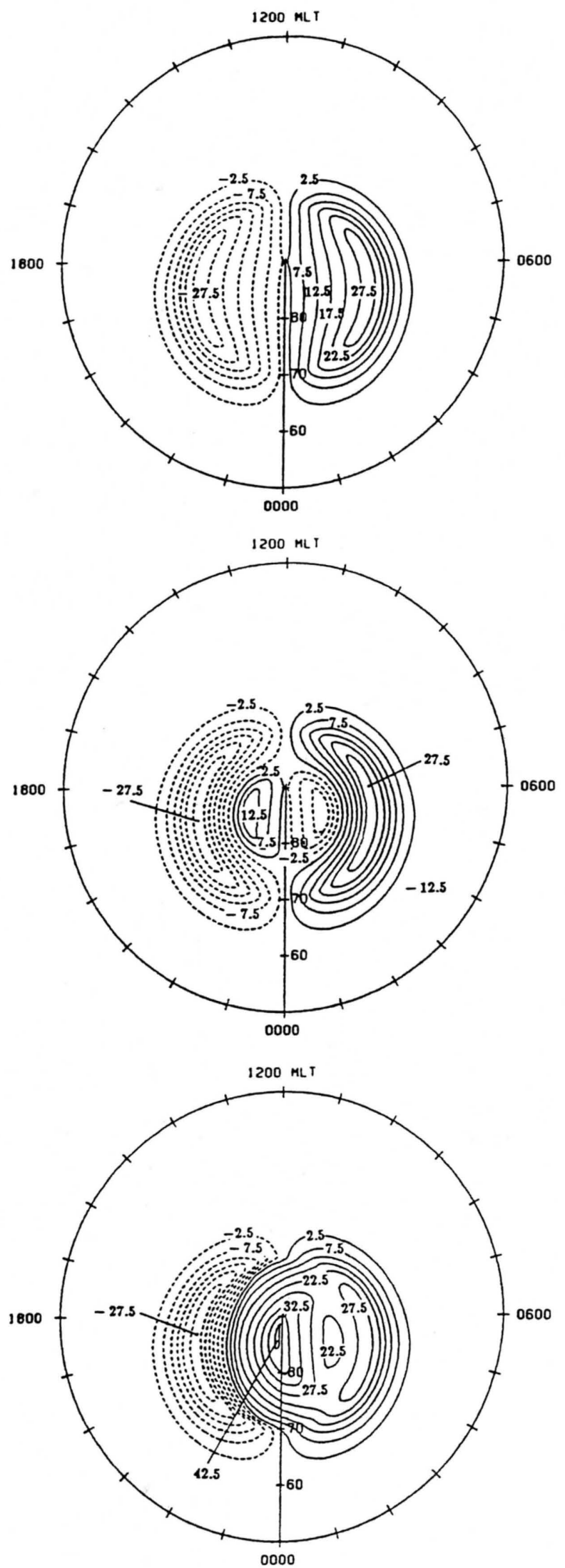

Fig. 1. Contours of potential for the two-cell (top panel), four-cell (middle panel), and three-cell (bottom panel) magnetospheric convection patterns. The contours are drawn at 5-kV intervals and are shown in a magnetic latitude MLT polar plot. Dashed lines indicate contours of negative potential.
In addition to multicell convection patterns, sun-aligned polar cap auroral arcs occur when the IMF is northward [Ismail and Meng, 1982; Gussenhoven, 1982; Frank et al., 1986]. Under certain conditions one of these arcs can be significant longer than the others and can extend all the way from the night sector to the dayside auroral oval. This feature in its entirety has been observed by the images on the DE 1 spacecraft and has been named the "theta" aurora [Frank et al., 1982, 1986]. Although an understanding of this phenomenon is limited, it appears that the sun-aligned arc (theta bar) is associated with a region of sunward convection.

Recently, Frank et al. [1986] have conducted a detailed study of four individual occurrences of theta aurora and associated convection using measurements from both the low-altitude DE 2 and the high-altitude DE 1 spacecraft. For these observations, two general states of the polar cap were found for northward IMF. The one state contained a bright, well-developed transpolar arc, and the associated plasma convection in the polar cap was sunward. Elsewhere in the polar cap, the plasma convection was predominantly antisunward. This convection signature, coupled with the convection observed in the auroral zone, suggested the presence of four convection cells. For this state, electron precipitation occurred in the theta aurora and was relatively absent over the rest of the polar cap region. The second state observed by Frank et al. [1986] was characterized by a dim or absent transpolar arc, a plasma convection pattern that is turbulent, and a complex system of polar arcs and glows over almost the entire polar cap region. Statistically, the second of these states appears to be the more common, although no detailed study has yet been conducted to quantify this fact.

Although much work has been done in modeling the ionospheric response to two-cell plasma convection [Knudsen et al., 1977; Spiro et al., 1978; Watkins, 1978; Sojka et al., 1981a,b, 1982; Schunk and Sojka, 1982a,b; Sojka and Schunk, 1983, 1984, 1985; Schunk et al., 1986; Rasmussen et al., 1986; Quegan et al., 1982], to our knowledge no attempts have been made at elucidating the ionospheric signatures associated with multicell convection patterns. This study therefore corresponds to a first step in this direction. In order to obtain clear ionospheric signatures, we have concentrated on modeling the "first state" described by Frank et al. [1986]. However, our study is qualitative in nature and we have not attempted to model the exact orbits reported by these authors owing to the lack of required input data. Specifically, the DE satellite measurements were limited to an individual orbit which cut across the polar region in a specific location for a brief $(\sim 10 \mathrm{~min})$ period of time. Our ionospheric model, however, requires plasma convection and particle precipitation information over the entire polar region throughout the day. Consequently, the DE data were used only as a general motivation for this study.

\section{Multicell Convection Patterns}

In this section we adopted three convection patterns which highlight the extremes of two-, three-, and four-cell polar convection. The convection models are all for the same level of geomagnetic activity, $K p=3$, but differ in that the IMF has different orientations. Table 1 lists the IMF orientations associated with the three convection models. This study uses the multicell convection model of Sojka et al. [1986].

Figure 1 shows the potential distribution for each of the three cases. Each panel is a magnetic latitude MLT polar plot centered on the north magnetic pole. The top panel represents the 
TABLE 1. Interplanetary Magnetic Field Components

\begin{tabular}{rrrrl}
\hline Case & $B_{x}$ & $B_{y}$ & $B_{z}$ & Description \\
\hline 1 & 0.0 & 0.0 & -18.0 & two-cell convection \\
2 & 0.0 & 0.0 & +18.0 & four-cell convection \\
3 & 0.0 & -24.0 & +18.0 & three-cell convection \\
\hline
\end{tabular}

$B_{x}, B_{y}$, and $B_{z}$ are in gammas.

conventional two-cell polar cap pattern of the Volland-Heelis type with a cross polar cap potential of $62 \mathrm{kV}$. The polar region does not show purely antisunward plasma flow that would normally be associated with a Volland pattern, and yet, it does not show a marked Heelis throat either. Equatorward of the polar cap, the dawn-dusk regions of sunward convection are symmetric. The polar cap dawn-dusk electric field is about 15 $\mathrm{mV} / \mathrm{m}$ and is uniform over the whole polar cap.

Figure 1, middle panel, shows the extreme case of four-cell convection, corresponding to an IMF which is purely northward (see Table 1). Two small reverse convection cells are present in the polar cap. As a result, the original two cells are distorted into "banana-" shaped convection regions. Equatorward of the original polar cap boundary, the convection pattern is identical to that in the top panel as well as in the bottom panel. In the center of the reverse convection cells the electric field is dusk-dawn orientated with a magnitude of about $25 \mathrm{mV} / \mathrm{m}$. Outside this reverse convection region in the dawn and dusk regions, the conventional dawn-dusk electric field reaches about $60 \mathrm{mV} / \mathrm{m}$. The enhanced convection associated with the larger electric field is in both the noon and midnight directions. At both noon and midnight a marked throat geometry is evident.

Three-cell convection is shown in the bottom panel of Figure 1. This pattern is associated with a northward IMF which has a strong negative $B_{y}$ component. Compared to both the two- and four-cell patterns, which showed dawn-dusk cell symmetry, this pattern has no dawn-dusk symmetry. The original dusk cell is "banana-" shaped; however, the dawn cell has expanded to fill part of the dusk polar cap and is "apple-" shaped. Inside the large dawn cell there is a region of reverse convection which consists of primarily a dusk component and a negligible dawn component. Since this dawn component is very small, the pattern basically has three cells. The reverse dusk-dawn electric field is now located in the dawn region of the polar cap and is about $25 \mathrm{mV} / \mathrm{m}$, whereas the entire dusk sector of the polar cap has primarily a dawn-dusk electric field of between $50 \mathrm{mV} / \mathrm{m}$ and $120 \mathrm{mV} / \mathrm{m}$. The larger electric fields are near the noon and midnight reversal region.

In combination with the earth's magnetic field the imposed convection electric field causes the plasma to $\mathbf{E} \times \mathbf{B}$ drift. The magnitude of this drift velocity at $300 \mathrm{~km}$ is shown in Figure 2 for each of the three convection cases. Each panel is a polar magnetic latitude MLT plot and the speed is contoured at $200-\mathrm{m} / \mathrm{s}$ intervals. All three patterns have the same speed distributions equatorward of the polar cap. At the polar cap boundary, between 0300 and 0800 and 1600 and 2100 MLT, the speed is about $900 \mathrm{~m} / \mathrm{s}$. For the two-cell pattern (top panel) the convection speed in the polar cap is roughly constant at about $350 \mathrm{~m} / \mathrm{s}$. For the four-cell pattern (middle panel) the convection speed maximizes at both the dawn and dusk edges of the polar cap with speeds of $950 \mathrm{~m} / \mathrm{s}$; the reverse convection region has speeds of about $400 \mathrm{~m} / \mathrm{s}$. The noon and midnight throat regions have lower speeds, of the order of $200-400 \mathrm{~m} / \mathrm{s}$. In contrast, for
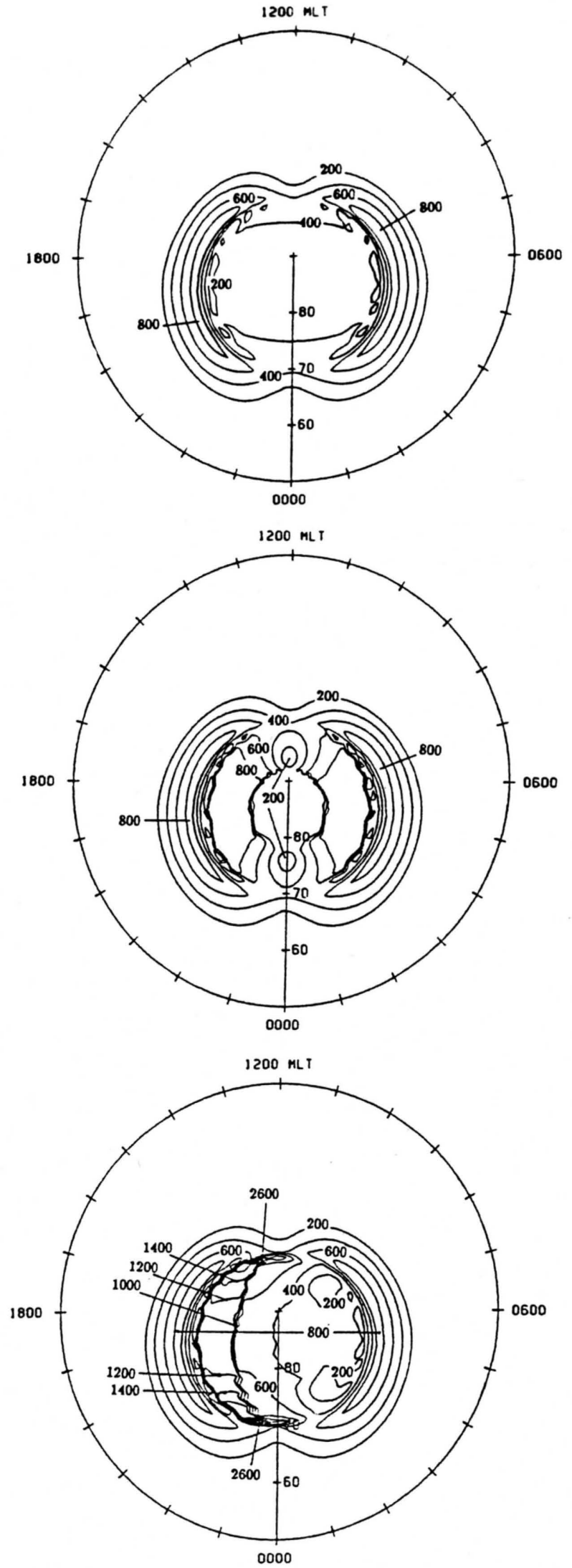

Fig. 2. Contours of horizontal plasma flow speed for the two-, four-, and three-cell magnetospheric convection patterns are shown in the top, middle, and bottom panels, respectively. The contours are drawn at $200-\mathrm{m} / \mathrm{s}$ intervals and are plotted in the same magnetic latitude MLT coordinate system as in Figure 1. 

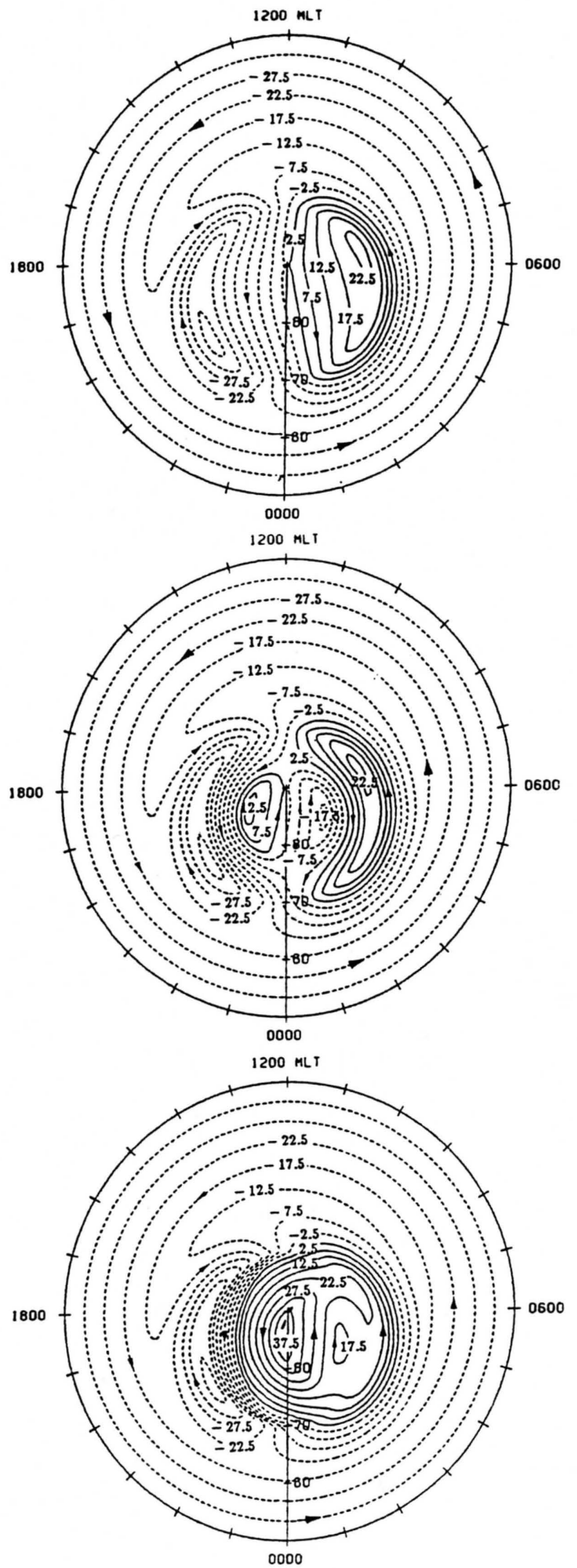

Fig. 3. Contours of potential for the combination of corotation with two-, four-, and three-cell magnetospheric convection are shown in the top, middle, and bottom panels, respectively. The contours are drawn at $5-\mathrm{kV}$ intervals and are shown in the magnetic latitude MLT reference frame. The potential is drawn relative to an arbitrary zero, with negative potentials being shown as dashed lines. the three-cell pattern (bottom panel) the convection speed maximizes on the duskside of the noon and midnight reversal regions, with speeds of about $2600 \mathrm{~m} / \mathrm{s}$. Inside the reverse convection region the speed is the same as for the four-cell case, except that the entire region is located in the dawn sector of the polar cap. These differences in polar cap convection speeds between the three cases result in different polar cap transit times, and consequently, differences in polar cap densities, as will be shown later.

Not only are the convection speeds different for the three convection patterns, but the plasma trajectories are also different. Figure 3 shows the contours of total potential, which is the sum of a corotational potential and the potentials shown in Figure 1. These equipotential contours also correspond to plasma flux tube trajectories in the $F$ region of the ionosphere. In the polar regions the three cases are quite dissimilar. However, each case has the same mid-latitude stagnation region located at $2100 \mathrm{MLT}$ and $62^{\circ}$ magnetic latitude. Arrows indicate the plasma flow directions in each panel.

The two-cell (top panel) transpolar cap flow is almost purely in the antisunward direction, while for the four-cell (middle panel) case a small region at the center of the polar cap shows sunward flow. The main antisunward flow region for this latter case follows the dawn and dusk polar cap boundaries around this central reverse flow region. However, some plasma flux tubes originating at noon first move around the dusk sector polar cap and then are driven in the sunward direction through the reverse flow region. These plasma flux tubes take over 24 hours to circulate [see Sojka et al., 1986]. In contrast, the adjacent dusk sector plasma flux tubes move across the polar cap in under 1 hour and circulate in about 3-4 hours. Associated with the four-cell case are two regions near the middle of the polar cap which locally circulate and never leave the polar cap. Such regions are not present in two-cell flow geometries. Finally, the bottom panel shows the three-cell case, where again flux tubes near the middle of the polar cap never leave the polar region. The main feature associated with this case is the lack of poleward flow into the polar cap at noon and vice versa out of the polar cap at midnight. In both regions the flow is primarily eastward with a smaller poleward/equatorward component. These strong flows are consistent with observations of throatlike features for strong $B_{y}$ IMF conditions [Heelis and Hanson, 1980].

\section{High-LATITUde IONOSPheric MODEL}

The ionospheric model was initially developed as a midlatitude, multiion $\left(\mathrm{NO}^{+}, \mathrm{O}_{2}^{+}, \mathrm{N}_{2}^{+}\right.$, and $\left.\mathrm{O}^{+}\right)$model by Schunk and Walker [1973]. The time-dependent ion continuity and momentum equations were solved as a function of altitude for a corotating plasma flux tube including diurnal variations and all relevant $E$ and $F$ region processes. This model was extended to include high-latitude effects due to convection electric fields and particle precipitation by Schunk et al. [1975, 1976]. A simplified ion energy equation was also added, which was based on the assumption that local heating and cooling processes dominate (valid below $500 \mathrm{~km}$ ). Flux tubes of plasma were followed as they moved in response to convection electric fields. A further extension of the model to include the minor ions $\mathrm{N}^{+}$and $\mathrm{He}^{+}$, an updated photochemical scheme, and the mass spectrometer/ incoherent scatter (MSIS) atmospheric model is described by Schunk and Raitt [1980].

The addition of plasma convection and particle precipitation 

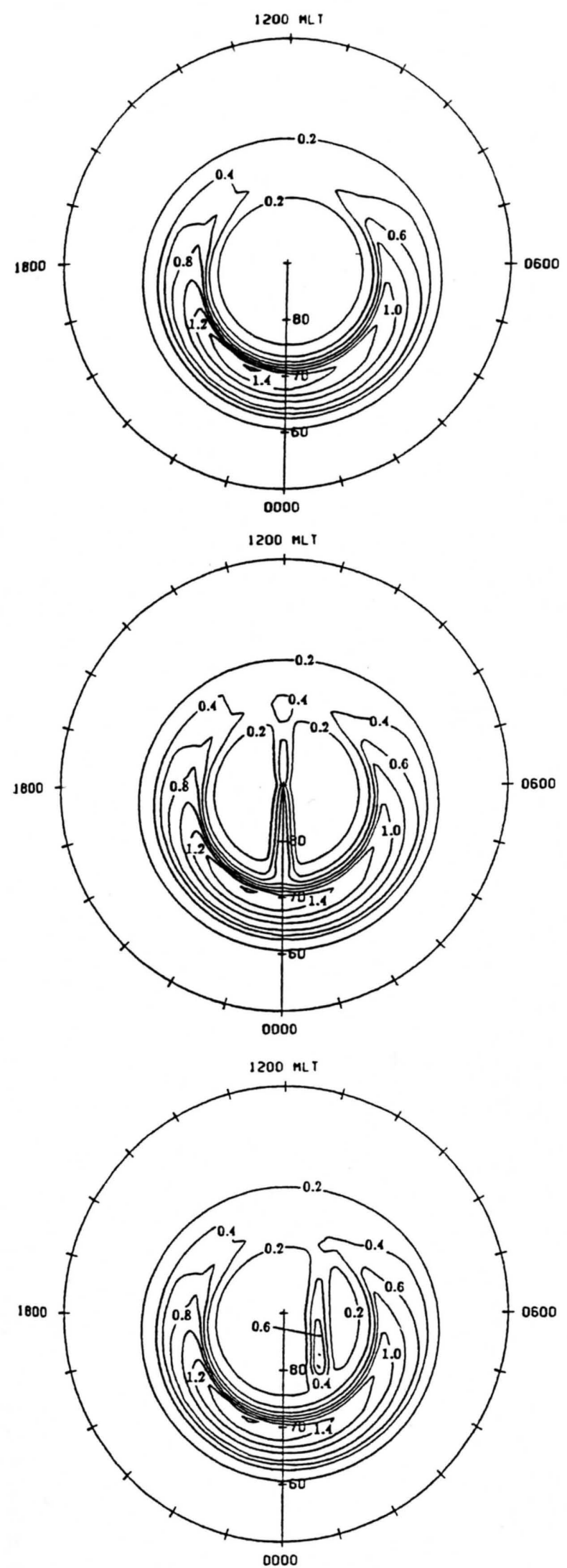

Fig. 4. Contours of the adopted precipitating electron energy flux associated with two-, four-, and three-cell magnetospheric convection are shown in the top, middle, and bottom panels, respectively. The contours are drawn at $0.2-\mathrm{erg} / \mathrm{cm}^{2} \mathrm{~s}$ intervals. The same coordinate system as in Figure 1 is used. models is described by Sojka et al. [1981a, b]. More recently, the ionospheric model has been extended by Schunk and Sojka [1982a] to include ion thermal conduction and diffusionthermal heat flow, so that the ion temperature is now rigorously calculated at all altitudes between $120-1000 \mathrm{~km}$. The adopted ion energy equation and conductivities are those given by Conrad and Schunk [1979].

Even though we are focusing attention on the convection models in this study, a number of other parameters, which are inputs to the ionospheric model, need to be described. The solar EUV and neutral atmosphere (MSIS) were specified by choosing the following solar and seasonal conditions: 1981 day 321, solar maximum, winter. Specifically, an $A p$ of 30 and an $F_{10.7}$ of 170 were adopted for this study. In addition, a simplistic neutral wind, flowing antisunward over the polar cap with a speed of $200 \mathrm{~m} / \mathrm{s}$, was used. This wind pattern is described by Sojka et al. $[1981 a, b]$. For the purposes of this study we kept the same polar cap wind. This procedure is not rigorous for the three- and four-cell cases where sunward ion flow occurs, but at present there is very little information on the thermospheric wind pattern for multicell convection. However, it is noted that near the pole the major effect associated with a thermospheric wind, the induced vertical ion drift, is very small due to the fact that the magnetic field is almost perpendicular to the wind.

At high latitudes the other main magnetospheric input is the auroral oval, which acts both as a plasma production and a heat source. Figure 4 shows the adopted auroral patterns for each case study. The oval is shown as contours of the electron energy flux in ergs per square centimeter per second in a magnetic latitude MLT polar plot. These panels are ordered in the same manner as in Figures 1-3. For the case of two-cell convection (top panel) the oval corresponds to the conventional Spiro et al. [1982] auroral energy flux model for an $A E$ value of 400 . The strongest precipitation occurs in the night sector oval, with fluxes reaching $1.6 \mathrm{erg} \mathrm{cm}^{-2} \mathrm{~s}^{-1}$. These high fluxes all lie outside of the polar cap region (compare with the top panel in Figure 1).

In the three- and four-cell cases a certain amount of precipitation occurs in the polar cap which is associated with the theta aurora signature [Frank et al., 1986]. To date, no empirical or theoretical model describes this polar cap precipitation. However, some evidence indicates that the precipitation lies in the region of sunward convection [Frank et al., 1986]. We therefore created theta bars for the three- and four-cell convection cases. Figure 4 (middle panel) shows the four-cell "theta" auroral precipitation model. The bar which runs from noon to midnight is about $6^{\circ}$ wide $(\sim 600 \mathrm{~km})$ and has the strongest precipitation located in the night sector, with the energy flux reaching $0.7 \mathrm{erg}$ $\mathrm{cm}^{-2} \mathrm{~s}^{-1}$ at a characteristic energy of $1 \mathrm{keV}$. Similarly, for the three-cell case (bottom panel) we placed a bar in the dawn sector through the region of sunward convection, and again, the energy flux reaches about 0.7 ergs $\mathrm{cm}^{-2} \mathrm{~s}^{-1}$ at $1-\mathrm{keV}$ characteristic energy. For both the three- and four-cell cases we used the Spiro et al. [1982] model to describe the main auroral region. These adopted theta precipitation patterns are highly speculative, and more measurements are needed before rigorous modeling can be done.

Using the ionospheric model, the various inputs, and the convection cases described in section 2, three specific ionospheric density studies were made. For each run, more than 35 trajectories were followed for more than 30 hours in order to build up a data set of density profiles for 12 equally spaced universal time (UT) intervals over the northern hemisphere 

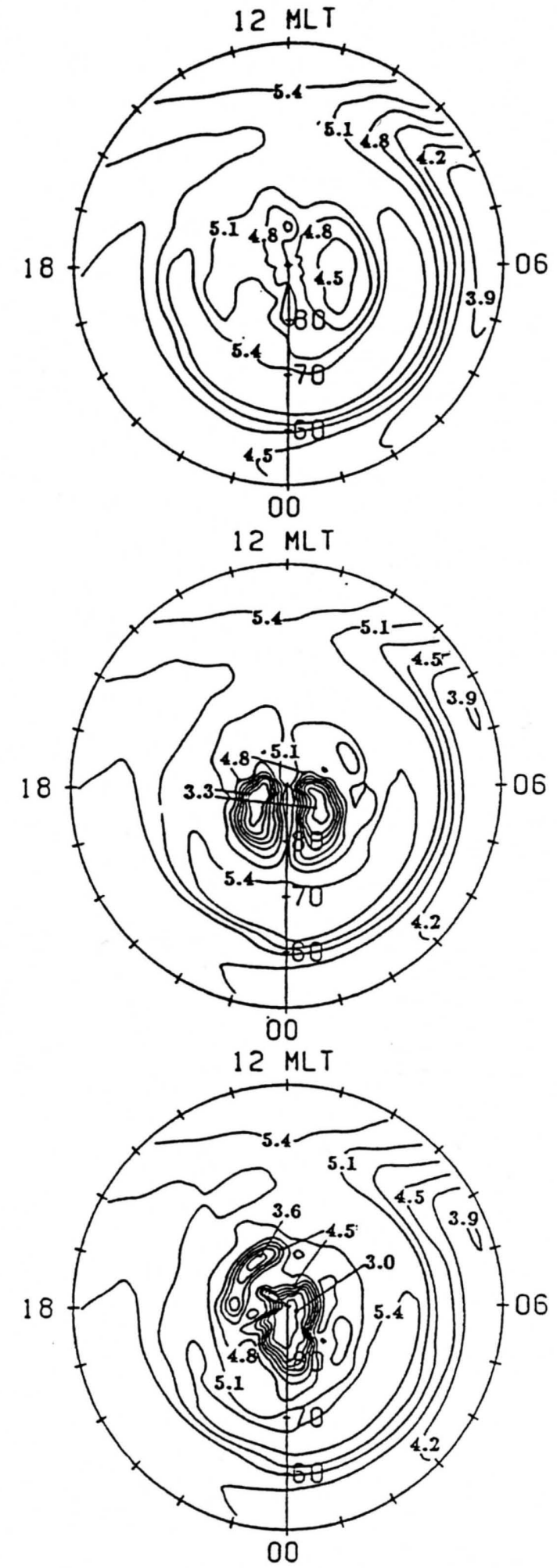

Fig. 5a. Contours of $\log _{10} \mathrm{O}^{+}$density $\left(\mathrm{cm}^{-3}\right)$ at $250 \mathrm{~km}$ for the two-, four-, and three-cell studies are shown in the top, middle, and bottom panels, respectively. The contours are drawn at intervals of 0.3 and are plotted in the same reference frame as in Figure 1. The densities are for 0500 UT.

poleward of $50^{\circ}$ magnetic latitude. For each study the solar and magnetospheric inputs were fixed for the entire simulation period ( $\approx 24$ hours). In the following sections the three studies are contrasted using a variety of ionospheric parameters in order to elucidate the characteristic ionospheric signatures that might be associated with multicell convection patterns.

\subsection{UT Dependence of $\mathrm{O}^{+}$at $250 \mathrm{~km}$}

In our previous studies we demonstrated the strong ionospheric dependence on UT [Sojka et al., 1981a, b, 1982]. This dependence arises from the UT motion of the solar terminator across the geomagnetic polar region. Hence the first parameter we examined is the $\mathrm{O}^{+}$density at $250 \mathrm{~km}$ for two UTs, namely 0500 and $1700 \mathrm{UT}$. Figure $5 a$ shows contours of $\log _{10}\left(\mathrm{O}^{+}\right)$density for the two-cell (top panel), four-cell (middle panel), and three-cell (bottom panel) convection models in the magnetic latitude MLT reference frame. The densities are for $0500 \mathrm{UT}$, and the contours are drawn at intervals of 0.3 on a $\log _{10}$ scale. As expected from the selection of convection models, all three cases show the same mid-latitude $\mathrm{O}^{+}$variation. Around noon, the dayside $\mathrm{O}^{+}$densities reach $3.0 \times 10^{5} \mathrm{~cm}^{-3}$, while the mid-latitude trough (0400-0800 MLT) $\mathrm{O}^{+}$densities drop below $7.0 \times 10^{3} \mathrm{~cm}^{-3}$ for this winter study.

The two-cell (top panel) $\mathrm{O}^{+}$densities show a minimum of about $3 \times 10^{4} \mathrm{~cm}^{-3}$ in the center of the polar cap. Normally, the minimum $F$ region peak density $\left(N_{m} F_{2}\right)$ in winter in the polar cap occurs closer to the edge of the nightside auroral oval. In Figure $5 a$ (top panel), the $\mathrm{O}^{+}$densities are not equivalent to $N_{m} F_{2}$ because the selected altitude of $250 \mathrm{~km}$ is below $h_{m} F_{2}$ (see Figure 8) and because of the importance of molecular ions (see Figure 6). Hence the $\mathrm{O}^{+}$minimum does not necessarily correspond to the polar density minimum. Also, for solar maximum conditions the height of the peak density $\left(h_{m} F_{2}\right)$ lies above 300 $\mathrm{km}$. For four-cell convection a very different $\mathrm{O}^{+}$density distribution is found in the polar cap. Two deep $\mathrm{O}^{+}$density holes are present. These holes are colocated with the centers of the two reverse convection cells (middle panel, Figure 1). In the holes the $\mathrm{O}^{+}$densities drop below $2 \times 10^{3} \mathrm{~cm}^{-3}$ at $250 \mathrm{~km}$. The theta aurora bar (middle panel, Figure 3 ) causes the enhanced densities in the noon-midnight region between the two holes. In the theta bar region the $\mathrm{O}^{+}$density reaches $1.3 \times 10^{5} \mathrm{~cm}^{-3}$.

A further complication arises in the three-cell case. In the middle of the polar cap a single density hole $\left(\mathrm{O}^{+} \sim 1 \times 10^{3} \mathrm{~cm}^{-3}\right)$ is colocated with the center of the large reverse convection cell. The theta bar again leads to higher densities in the sunward convecting region. In addition to this polar cap depletion, a second density minimum is found in the dusk polar cap near noon. Here the $\mathrm{O}^{+}$density drops below $4 \times 10^{3} \mathrm{~cm}^{-3}$. This region is colocated with the very high plasma convection speed $(\sim 3$ $\mathrm{km} / \mathrm{s}$ ) region (bottom panel, Figure 3). High electric fields in the absence of solar or auroral plasma production are very efficient in converting $\mathrm{O}^{+}$to $\mathrm{NO}^{+}$[Schunk et al., 1976]. A similar depletion is not found in the high convection region near midnight because of the strong auroral precipitation present there.

Figure $5 b$ is identical to Figure $5 a$, except that the $\mathrm{O}^{+}$densities are plotted for $1700 \mathrm{UT}$, a time when the terminator is at its farthest poleward location. Comparing these two figures shows that the general features have not changed with UT; however, the densities have changed significantly. In the two-cell case (top panel) the $\mathrm{O}^{+}$density minimum is $6.3 \times 10^{4} \mathrm{~cm}^{-3}$, which is a factor of 2 larger than at $0500 \mathrm{UT}$. The increased density is associated with the terminator moving nearer this region, which allows high densities to convect into the region. This increase is also present in the four-cell density minima which are about a factor of 2 larger than at $0500 \mathrm{UT}$ (middle panels, Figures $5 a$ and $5 b$ ).

For three-cell convection (bottom panel) the $\mathrm{O}^{+}$density in the reverse convection cell is now a factor of 8 larger than that at 
18
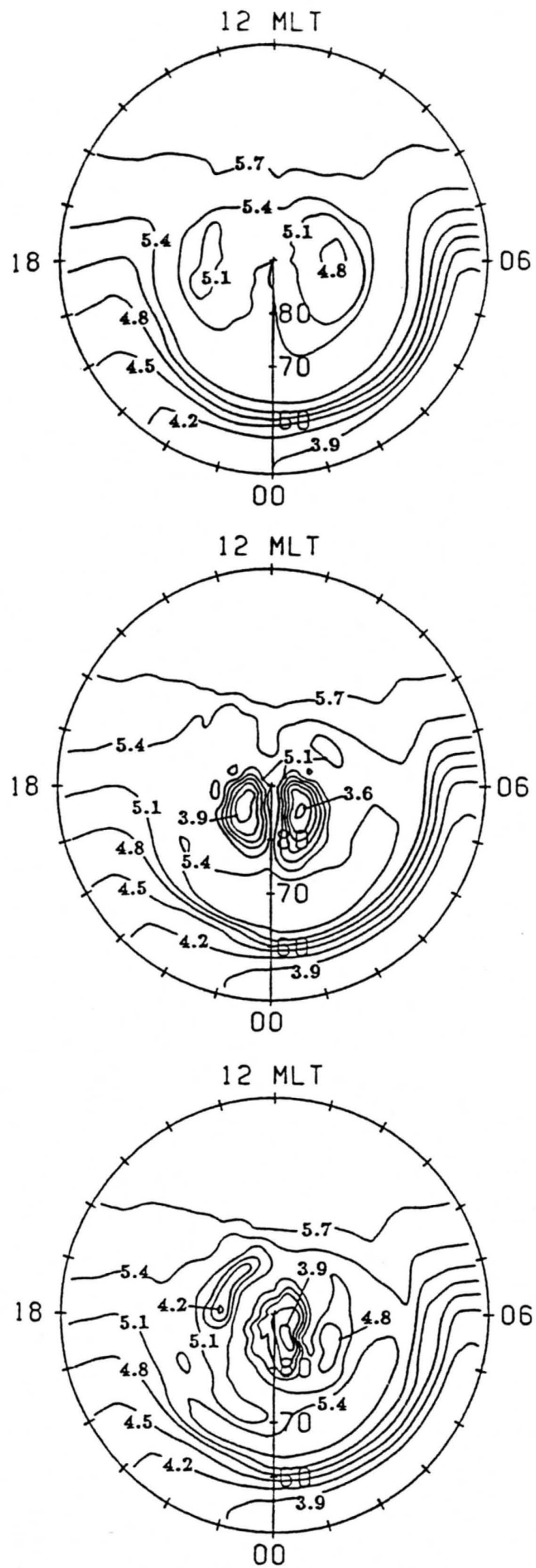
Fig. $5 b$. Same as Figure $5 a$ except that the $\mathrm{O}^{+}$densities are for 1700
UT.

0500 UT. This cell is much larger than the two reverse cells in the four-cell case, and the transport of high-density plasma from the sunlit part of the cell plays a more significant role in maintaining the density. The additional polar cap depletion region near noon at 0500 UT (Figure $5 a$ ) is now in sunlight. Consequently, the
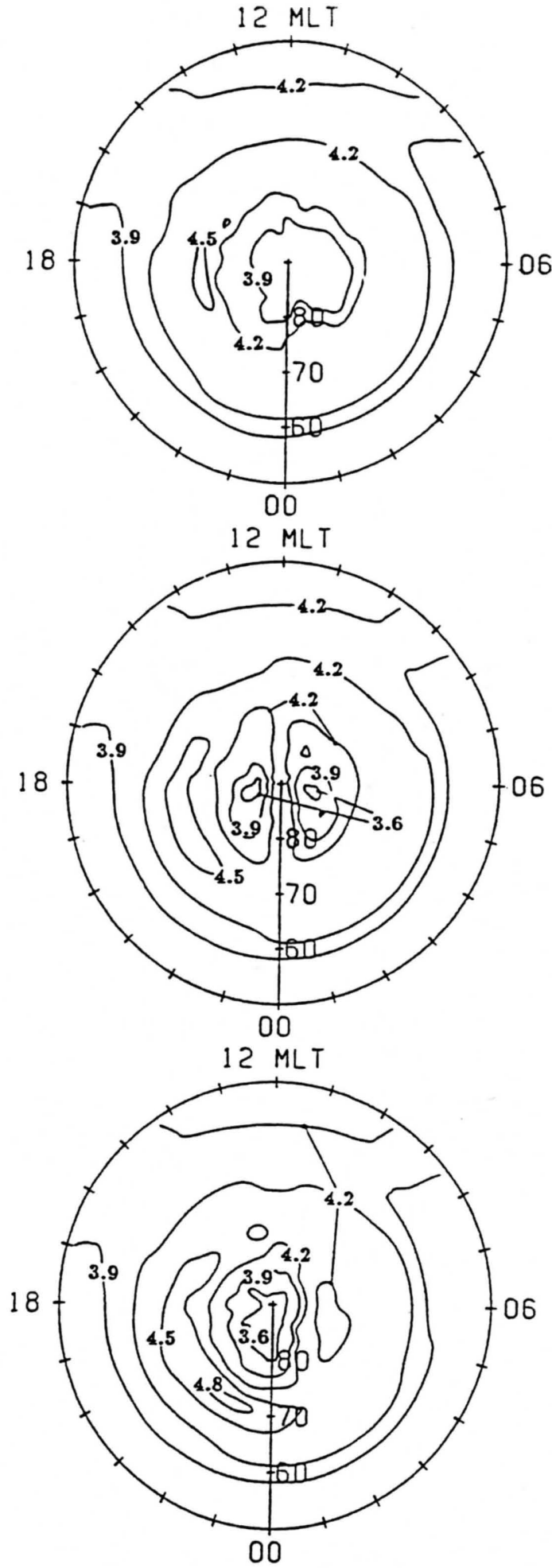

Fig. 6. Contours of the molecular ion density at $250 \mathrm{~km}$ for the two-, four-, and three-cell studies are shown in the top, middle, and bottom panels, respectively. The contours are drawn at intervals of 0.3 of $\log _{10}$ $\left(\mathrm{NO}^{+}+\mathrm{O}_{2}^{+}\right)$density in $\mathrm{cm}^{-3}$. The densities are shown in the same reference frame as in Figure 1 and are for 0500 UT.

density in this region has increased from $4 \times 10^{3} \mathrm{~cm}^{-3}$ to $1.5 \times$ $10^{4} \mathrm{~cm}^{-3}$.

The role of UT in this study is primarily to modify the densities in the polar cap features. Certain features associated with reverse convection cells can vary diurnally by more than a factor 

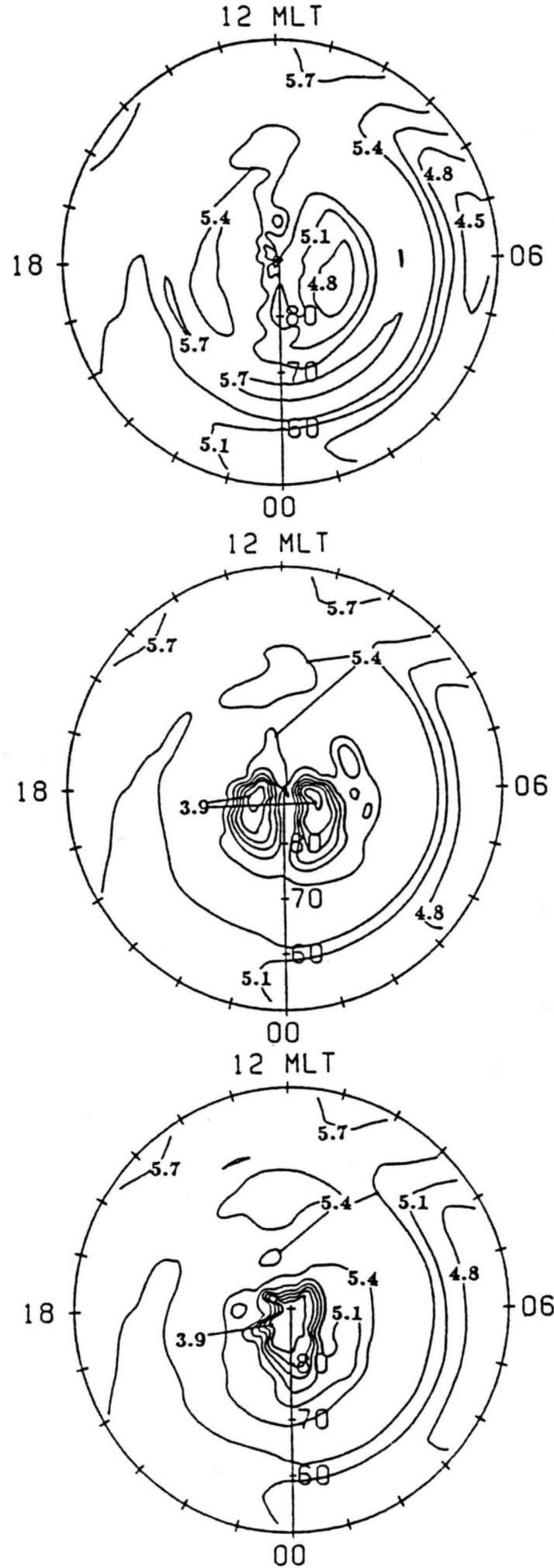

Fig. 7. $N_{m} F_{2}$ contours for the two-, four-, and three-cell studies are shown in the top, middle, and bottom panels, respectively. The $N_{m} F_{2}$ contours are labeled in $\log _{10}\left(\mathrm{~cm}^{-3}\right)$ units. The same reference frame as in Figure 1 is used and the $N_{m} F_{2}$ values are for $0500 \mathrm{UT}$.

of 2 in winter. These diurnal variations do not have the same UT phase. Although not shown here, the UT effect would be much less in summer when the polar cap is always sunlit, while at equinox it would be much larger. For the remainder of this study we only present ionospheric parameters for $0500 \mathrm{UT}$.

\subsection{Molecular Ions and Composition at $250 \mathrm{~km}$}

As was already pointed out in the previous section, $h_{m} F_{2}$ lies above $250 \mathrm{~km}$ during solar maximum, which implies that the molecular ions are important at this altitude. Figure 6 shows contours of $\log _{10}\left(\mathrm{O}_{2}^{+}+\mathrm{NO}^{+}\right)$density for the three convection models. Contours are drawn at intervals of 0.3 and labeled in $\log _{10}\left(\mathrm{~cm}^{-3}\right)$. These densities are for $0500 \mathrm{UT}$ and complement the $\mathrm{O}^{+}$densities shown in Figure $5 a$. The molecular ion density varies by typically only an order of magnitude, whereas the $0^{+}$ density varies by over $2 \frac{1}{2}$ orders of magnitude. In the two-cell case (top panel, Figure 6) the molecular ion density displays a small depletion in the polar cap, dropping by a factor of about 3 from the oval densities. In contrast, the $\mathrm{O}^{+}$density drops by a factor of 20 between these regions (see Figure $5 a$ ). Similar contrasts hold for the two polar depletion regions in the fourcell case (middle panel, Figure 6). The molecular ion density drops to about $4 \times 10^{3} \mathrm{~cm}^{-3}$ in the two polar holes, whereas it is about $3 \times 10^{4} \mathrm{~cm}^{-3}$ in the oval. In comparison, the $\mathrm{O}^{+}$hole is at a density of $2 \times 10^{3} \mathrm{~cm}^{-3}$, and the oval density is larger than $10^{5}$ $\mathrm{cm}^{-3}$. For the three-cell case (bottom panel) the molecular ion density in the large reverse convection cell drops below $4 \times 10^{3}$ $\mathrm{cm}^{-3}$. However, the second density depletion present in $\mathrm{O}^{+}$(bottom panels, Figure 5) is not present in the molecular ion case. This $\mathrm{O}^{+}$depletion is associated with large electric fields and is in a region where $\mathrm{O}^{+}$is converted into $\mathrm{NO}^{+}$very efficiently. In this region the molecular ion density is above $2 \times 10^{4} \mathrm{~cm}^{-3}$, whereas the $\mathrm{O}^{+}$density is below $4 \times 10^{3} \mathrm{~cm}^{-3}$.

The composition at $250 \mathrm{~km}$ varies from being $\mathrm{O}^{+}$dominated to almost entirely molecular. In the dayside solar illuminated regions and in the auroral oval the composition is dominated by $\mathrm{O}^{+}$, with a density ratio of $\mathrm{O}^{+} /\left[\mathrm{NO}^{+}+\mathrm{O}_{2}^{+}\right]$of about eight. Along the theta bar auroral structure in the four- and three-cell cases this density ratio is also about eight. In all the polar (and also mid-latitude) depletion regions the composition is dominated by the molecular ions. For the four- and three-cell cases these depletion regions are associated with plasma circulation patterns which are restricted to the polar cap. In these polar depletion regions the ion density ratio ranges from 0.3 to 0.5 , which is significantly smaller than that in the dayside and oval regions. The three-cell case had an additional depletion in $\mathrm{O}^{+}$that was associated with large electric fields. In this region the molecular ions do not show a depletion, and hence the ion density ratio, $\mathrm{O}^{+} /\left[\mathrm{NO}^{+}+\mathrm{O}_{2}^{+}\right]$, is less than 0.2 . A wide variety of compositional changes are associated with multicell convection/auroral precipitation patterns inside the polar cap. This variety is much more extensive than that associated with the conventional twocell convection pattern. These composition ratios show a marked dependence on altitude, since $250 \mathrm{~km}$ is on the bottomside of the $F$ layer where strong altitudinal density gradients of opposite sign exist for $\mathrm{O}^{+}$and the molecular ions.

\section{3. $N_{m} F_{2}$ and $h_{m} F_{2}$}

In the previous subsections we presented the $\mathrm{O}^{+}$density and the ion composition at a fixed altitude $(250 \mathrm{~km})$. The $F$ region peak density $\left(N_{m} F_{2}\right)$ does not lie at a fixed altitude. For the solar maximum conditions of this study the height of the peak density $\left(h_{m} F_{2}\right)$ normally lies above $250 \mathrm{~km}$. Figure 7 shows contours of $\log _{10}\left(N_{m} F_{2}\right)$ for the three convection models. Contours are labeled in units of $\log _{10}\left(\mathrm{~cm}^{-3}\right)$ and are drawn at intervals of 0.3 . The two-cell case (top panel) shows a mid-latitude trough of about $4 \times 10^{4} \mathrm{~cm}^{-3}$ and a polar depletion region with a similar density. In the polar cap the depletion is located in the morning 

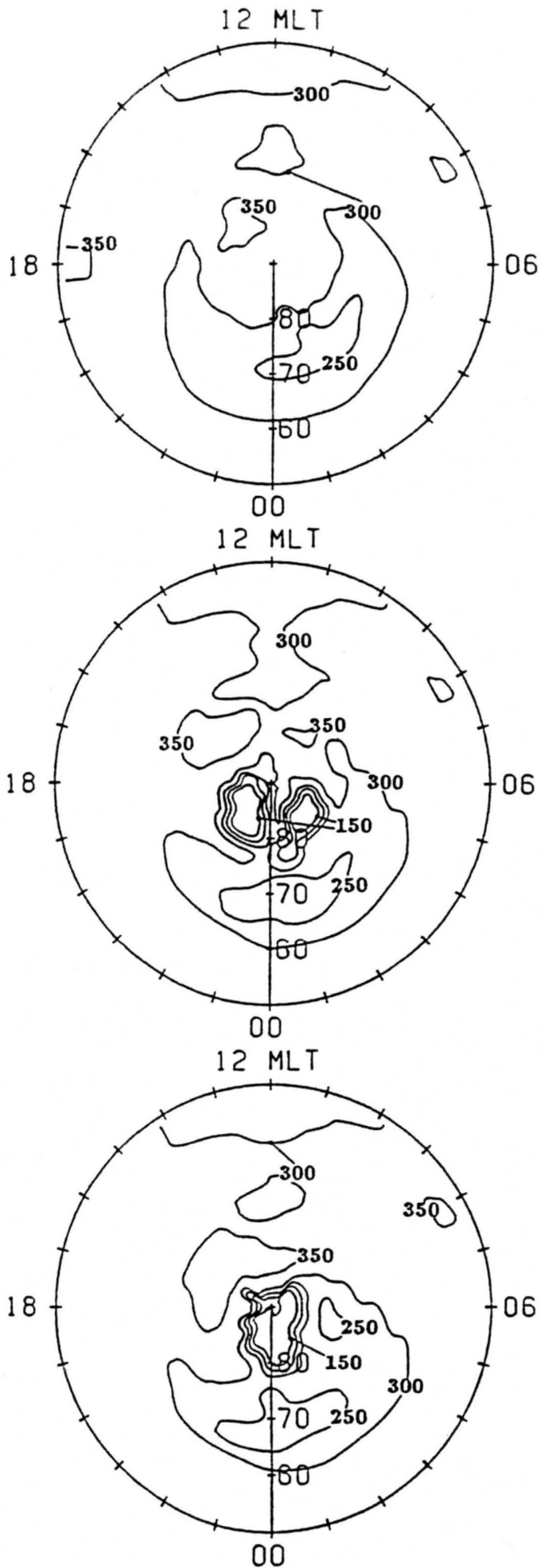

Fig. 8. The $h_{m} F_{2}$ contours for the two-, four-, and three-cell studies are shown in the top, middle, and bottom panels, respectively. The $h_{m} F_{2}$ contours are labeled in kilometers. The same reference frame as in Figure 1 is used, and the $h_{m} F_{2}$ values correspond to $0500 \mathrm{UT}$.

sector past the pole toward midnight. This location is different from the $\mathrm{O}^{+}$depletion at $250 \mathrm{~km}$ (top panel, Figures $5 a$ and $5 b$ ); it is associated with the overall transpolar transport and decay of plasma. The minimum occurs just before the plasma convects into the night sector oval.

Polar cap depletions in $N_{m} F_{2}$ are found in the reverse convec- tion cells associated with the four-cell (middle panel) and threecell (bottom panel) convection patterns. These depletions are colocated with the lower altitude $\mathrm{O}^{+}$depletions (Figures $5 a$ and $5 b$ ). However, the additional depletion in $\mathrm{O}^{+}$for the three-cell case, which was associated with high convection, is not present in $N_{m} F_{2}$. The noon region on the duskside of the polar cap does not display a variation in $N_{m} F_{2}$ where the marked $\mathrm{O}^{+}$depletion at $250 \mathrm{~km}$ was located. For the four- and three-cell polar cap depletions, $N_{m} F_{2}$ drops below $8 \times 10^{3} \mathrm{~cm}^{-3}$, whereas for the two-cell case the lowest polar cap densities are only $6 \times 10^{4} \mathrm{~cm}^{-3}$, almost an order of magnitude larger.

Figure 8 shows contours of $h_{m} F_{2}$ for the three convection models in the same magnetic latitude MLT reference frame. Contours are labeled in kilometers and drawn at 50-km intervals. For solar maximum the basic $h_{m} F_{2}$ values lie near $330 \mathrm{~km}$. Inside the main evening sector auroral region, which also corresponds to the region where the convection velocity is directed equatorward, producing downward plasma drifts, the $h_{m} F_{2}$ values drop below $250 \mathrm{~km}$. In contrast, in the dayside throat region, where the plasma flows poleward into the polar cap, $h_{m} F_{2}$ increases to about $350 \mathrm{~km}$. This region increases in size with increasing convection speed from the two- to four- to three-cell cases. The regions of high $h_{m} F_{2}$ do not show duskdawn symmetry; $h_{m} F_{2}$ is elevated only in the dusk sector. From the plasma trajectories in Figure 3 this asymmetry is also present and is the reason for the $h_{m} F_{2}$ asymmetry. In the middle of the reverse convection cells, four- and three-cell cases (middle and bottom panels), $h_{m} F_{2}$ drops below $150 \mathrm{~km}$. These deep polar depletions are regions of closed circulations with very little plasma production. Resonantly scattered radiation is the dominant plasma source, with only a small amount of EUV production occurring for a few hours around $1700 \mathrm{UT}$. In these regions the bottomside $E$ region densities exceed the $F$ region densities.

\subsection{Topside $\mathrm{O}^{+}$Densities at $800 \mathrm{~km}$}

Figure 9 shows contours of the $\log _{10}\left(\mathrm{O}^{+}\right)$density at $800 \mathrm{~km}$ for the three convection models. Contours are labeled in $\log _{10}$ $\left(\mathrm{cm}^{-3}\right)$ and drawn at 0.3 intervals on a $\log _{10}$ scale. The two-cell convection model (top panel) produces a similar morphology to the previous $N_{m} F_{2}$ plot (top panel, Figure 7). At $800 \mathrm{~km}$ the polar hole has moved further toward the midnight oval. A difference in density of about an order of magnitude separates the high auroral oval densities of $\approx 5 \times 10^{4} \mathrm{~cm}^{-3}$ and the polar hole minimum densities of $\leqslant 3 \times 10^{3} \mathrm{~cm}^{-3}$. This decreasing trend is further heightened in the three-cell case (bottom panel), where the polar hole in the reverse convection cell drops below $5 \times 10^{1}$ $\mathrm{cm}^{-3}$. The three-cell high convection depletion region is not present at this altitude. Indeed, a slight enhancement is present, which arises from the increased scale height in the high convection region.

\section{5. $\mathrm{NO}^{+}+\mathrm{O}_{2}^{+}$Densities at $350 \mathrm{~km}$}

Figure 10 shows contours of the molecular ion density at 350 $\mathrm{km}$ for the three convection models. The contours are drawn at 0.3 intervals and labeled in $\log _{10}$. At this altitude, which is near or above the $F$ region peak, low molecular ion densities are expected. These densities are normally more than 2 orders of magnitude lower than the corresponding $\mathrm{O}^{+}$densities. In the dayside and auroral regions the peak $\mathrm{O}^{+}$density $\left(N_{m} F_{2}\right)$ is greater than about $5 \times 10^{5} \mathrm{~cm}^{-3}$, whereas the molecular ion density is only about $6 \times 10^{3} \mathrm{~cm}^{-3}$. However, in the polar deple- 
12 MLT

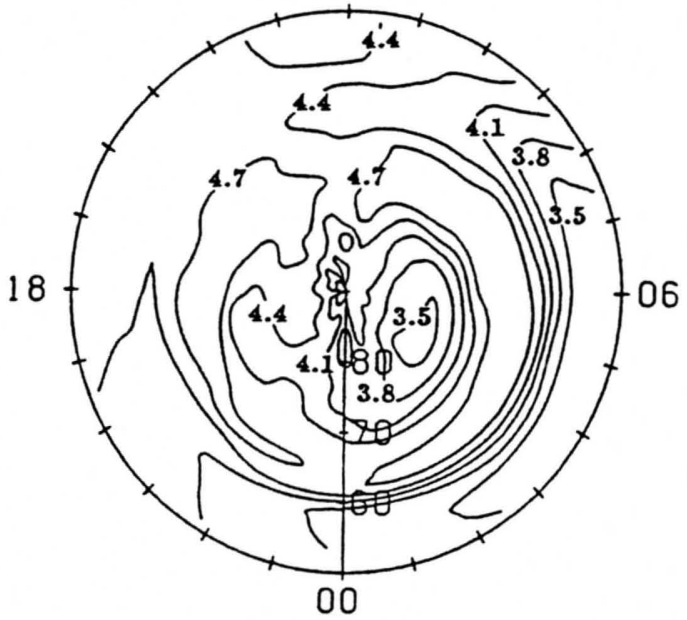

12 MLT
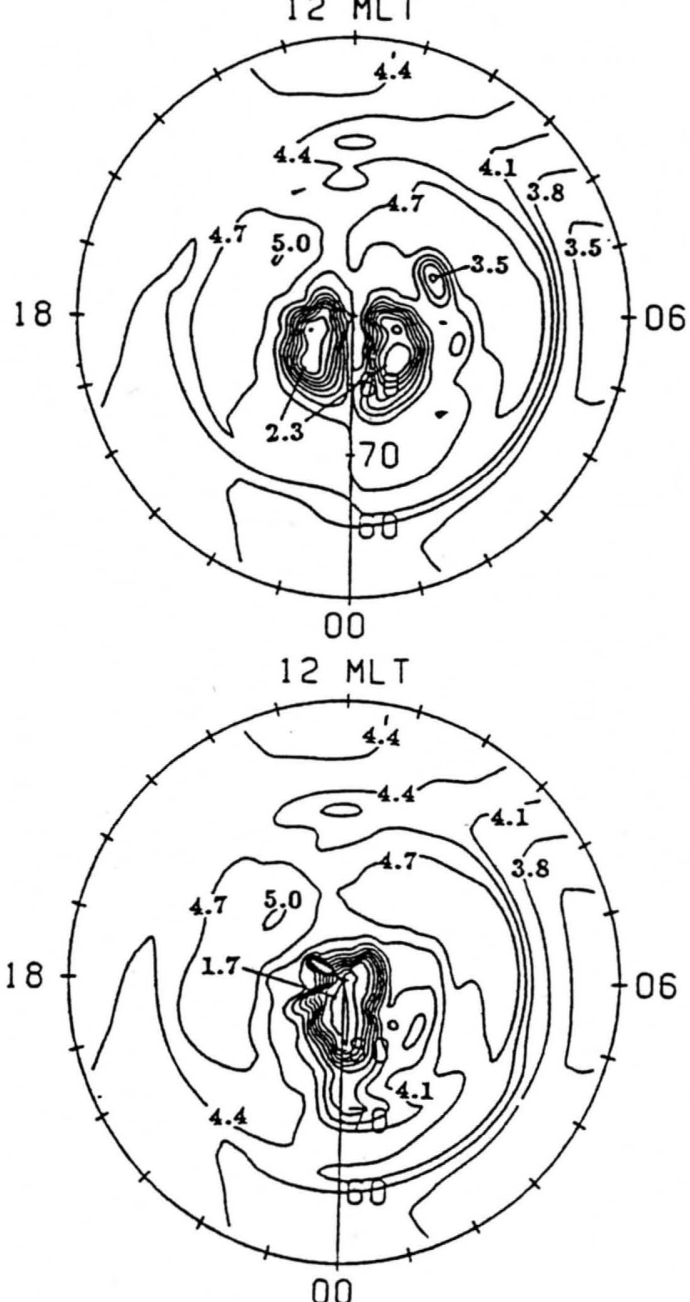

Fig. 9. Contours of $\mathrm{O}^{+}$density at $800 \mathrm{~km}$ for the two-, four-, and three-cell studies are shown in the top, middle, and bottom panels, respectively. The contours are labeled in units of $\log _{10}\left(\mathrm{~cm}^{-3}\right)$. The same reference frame as in Figure 1 is used, and the densities are for 0500 UT.

tion regions the atomic/molecular ion density ratio decreases to only 1 order of magnitude in the three- and four-cell cases.

For the three-cell case (bottom panel, Figure 10) the theta bar is located in the dawn sector, and again the molecular density is enhanced. An additional feature is present in the three-cell case;
12 MLT

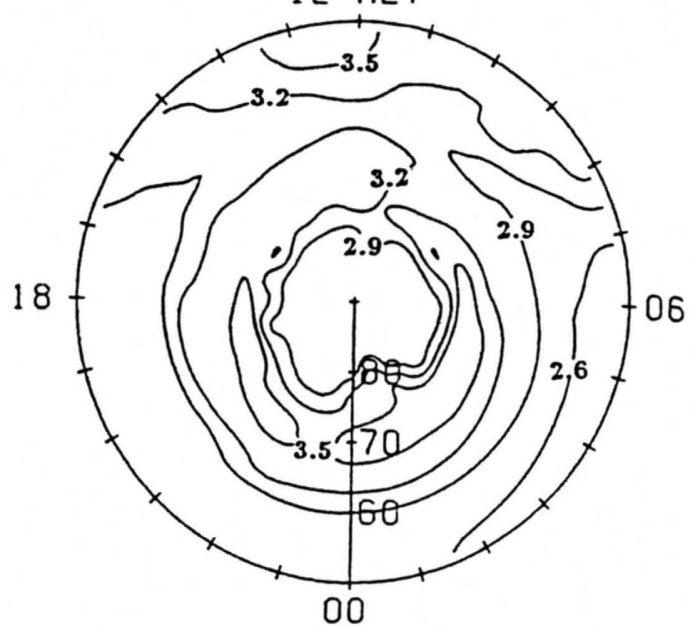

12 MLT

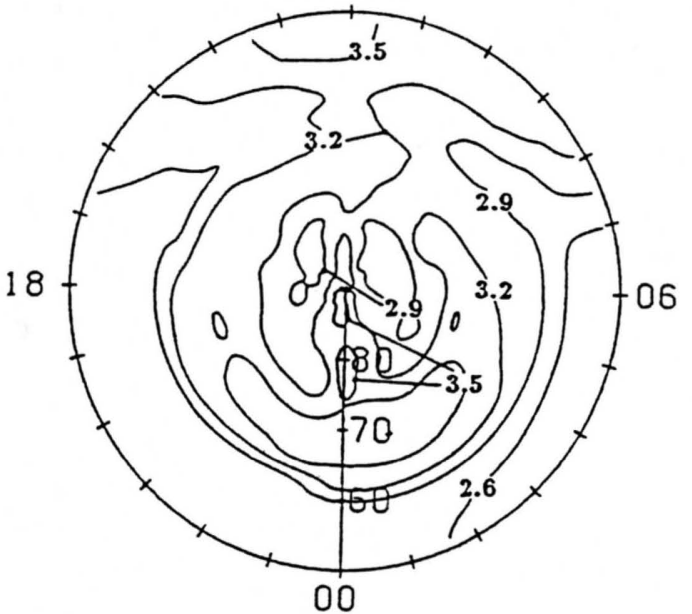

$12 \mathrm{MLT}$

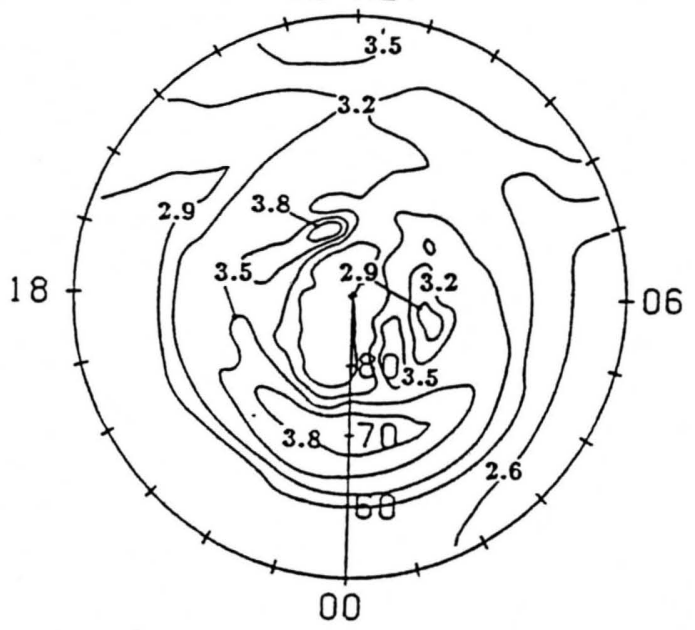

Fig. 10. Contours of the molecular ion density at $350 \mathrm{~km}$ for the two-, four-, and three-cell studies are shown in the top, middle, and bottom panels, respectively. The density contours are labeled in $\log _{10}\left(\mathrm{NO}^{+}+\right.$ $\left.\mathrm{O}_{2}^{+}\right) \mathrm{cm}^{-3}$. The plots are shown in the same reference frame as in Figure 1.

namely, in the noon sector of the dusk polar cap the density is enhanced. This enhanced molecular ion density is approximately colocated with the $\mathrm{O}^{+}$density depletion at $250 \mathrm{~km}$ and is a result of the high electric fields in this region. From earlier studies this region is also colocated with an ion temperature hot 
spot [Schunk and Sojka, 1982a]. In this region, neutral-ion heating is prevalent with electric fields of about $160 \mathrm{mV} / \mathrm{m}$. This feature is not directly associated with the reverse convection cell, but is rather a consequence of the convergence of transpolar plasma flow through a narrow channel around the reverse convection region. As a result, the local $\mathrm{NO}^{+}$density is enhanced by over an order of magnitude relative to surrounding regions. These high molecular ion densities are maintained by transport of $\mathrm{O}^{+}$into this location at $F$ region altitudes. The increased ion temperatures enhance the $\mathrm{O}^{+}+\mathrm{N}_{2}$ reaction rate, producing $\mathrm{NO}^{+}$.

\section{SUMMARY}

A time-dependent three-dimensional model of the highlatitude ionosphere was used to study the characteristic ionospheric signatures associated with two-, three-, and four-cell plasma convection patterns. For the multicell convection patterns, sunward convection and theta bar auroral precipitation were the important features in the polar cap. For the three cases the same cross-tail magnetospheric potential was used, and the calculations were performed for solar maximum and winter conditions in the northern hemisphere. In comparing the ionosphere's response to the different convection patterns we presented ion density distributions at 250,350 , and $800 \mathrm{~km}$, as well as the variation of $N_{m} F_{2}$ and $h_{m} F_{2}$ over the high-latitude region.

Our theoretical study focused attention on the maximum ionospheric contrast between a conventional two-cell polar cap and those possibly expected for fully developed three- and fourcell polar caps. In our study the convection patterns and associated auroral forms were fixed for 24 hours. We recognize that the IMF conditions are not likely to remain fixed for such a length of time, but we looked at fully developed and stable multicell configurations in order to have benchmarks against which to compare ionospheric signature of multicell convection patterns. In practice, we would expect the ionospheric features described in this paper to appear if the convection and auroral patterns are steady for time periods greater than 3-5 hours. How such time periods relate to solar wind-magnetosphere interaction times is currently not known.

From our study we found the following:

1. For two-cell convection the antisunward flow of plasma from the dayside into the polar cap acts to maintain the densities in this region in winter. In contrast, for four-cell convection the two additional convection cells in the polar cap are in darkness most of the time, and the resulting $\mathrm{O}^{+}$decay acts to produce twin polar holes that are separated by a sun-aligned ridge of enhanced ionization due to theta-aurora precipitation. For three-cell convection only one polar hole forms in the total electron density.

2. For three-cell convection an additional $\mathrm{O}^{+}$depletion region develops near noon. In this region there are strong electric fields, high ion temperatures, and an enhanced rate of $\mathrm{O}^{+} \longrightarrow \mathrm{NO}^{+}$conversion.

3. The above general distinguishing ionospheric features are evident at all universal times, but the ion densities can vary by an order of magnitude in some regions owing to the motion of the terminator relative to the magnetic pole.

4. The $\mathrm{O}^{+}$density variation at $250 \mathrm{~km}$ does not necessarily reflect the $N_{m} F_{2}$ variation, especially for the multicell convection patterns.

5. The variation of $h_{m} F_{2}$ over the polar region is greater for the multicell convection patterns than for two-cell convection.
In this study $h_{m} F_{2}$ varied from 150 to above $350 \mathrm{~km}$ for multicell convection.

6. In the polar cap the ion composition is generally much more uniform for two-cell convection than for multicell convection. For the adopted three- and four-cell convection patterns the atomic/molecular ion density ratio at $250 \mathrm{~km}$ varied from 0.2 to 8 in the polar cap.

The aim of this study was to elucidate the characteristic signatures associated with multicell convection patterns and therefore was intended to be qualitative in nature. Because of the lack of required input data we cannot, at this time, do a meaningful quantitative comparison between theory and measurements. However, we are currently working with experimentalists in an effort to acquire the needed data so that a quantitative test of model predictions for multicell convection patterns can be done in the future.

Acknowledgments. This research was supported by Air Force Office of Scientific Research contract F49620-86-C-0109, NASA grant NAGW-77, and National Science Foundation grant ATM-8417880 to Utah State University. The computer-modeling effort was supported by the National Center for Atmospheric Research, which is sponsored by the National Science Foundation.

The Editor thanks J. D. Kelly and N. Maynard for their assistance in evaluating this paper.

\section{REFERENCES}

Akasofu, S.-I., Recent progress in studies of DMSP auroral photographs, Space Sci. Rev., 19, 169-215, 1976.

Burch, J. L., S. A. Fields, and R. A. Heelis, Polar cap electron acceleration regions, J. Geophys. Res., 84, 5863-5874, 1979.

Burke, W. J., M. C. Kelley, R. C. Sagalyn, M. Smiddy, and S. T. Lai, Polar cap electric field structures with a northward interplanetary magnetic field, Geophys. Res. Lett., 6, 21-24, 1979.

Burke, W. J., M. S. Gussenhoven, M. C. Kelley, D. A. Hardy, and F. J. Rich, Electric and magnetic field characteristics of discrete arcs in the polar cap, J. Geophys. Res., 87, 2431-2443, 1982.

Conrad, J. R., and R. W. Schunk, Diffusion and heat flow equations with allowance for large temperature differences between interacting species, J. Geophys. Res., 84, 811-822, 1979.

Eather, R. H., and S.-I. Akasofu, Characteristics of polar cap arcs, $J$. Geophys. Res., 74, 4794-4798, 1969.

Evans, J. V., J. M. Holt, W. L. Oliver, and R. H. Wand, Millstone Hill incoherent scatter observations of auroral convection over $60^{\circ} \leq \Lambda \leq$ $75^{\circ}, 2$, Initial results, J. Geophys. Res., 85, 41-54, 1980.

Foster, J. C., An empirical electric field model derived from Chatanika radar data, J. Geophys. Res., 88, 981-987, 1983.

Foster, J. C., J. R. Doupnik, and G. S. Stiles, Large-scale patterns of auroral ionospheric convection observed with the Chatanika radar, J. Geophys. Res., 86, 11,357-11,371, 1981.

Foster, J. C., J. M. Holt, R. G. Musgrove, and D. S. Evans, Ionospheric convection associated with discrete levels of particle precipitation, Geophys. Res. Lett., 13, 656-659, 1986.

Frank, L. A., J. D. Craven, J. L. Burch, and J. D. Winningham, Polar views of the earth's aurora with Dynamics Explorer, Geophys. Res. Lett., 9, 1001-1004, 1982.

Frank, L. A., J. D. Craven, D. A. Gurnett, S. D. Shawhan, D. R. Weimer, J. L. Burch, J. D. Winningham, C. R. Chappell, J. H. Waite, R. A. Heelis, N. C. Maynard, M. Sugiura, W. K. Peterson, and E. G. Shelley, The theta aurora, J. Geophys. Res., 91, 3177-3224, 1986.

Greenwald, R. W., W. Weiss, E. Nielsen, and N. R. Thompson, STARE: A new radar auroral backscatter experiment in northern Scandinavia, Radio Sci., 13, 1021-1039, 1978.

Gussenhoven, M. S., Extremely high-latitude auroras, J. Geophys. Res., 87, 2401-2412, 1982.

Haerendel, G. R., R. Lust, and E. Reiger, Motion of artificial ion clouds in the upper atmosphere, Planet. Space Sci., 15, 1-18, 1967.

Hardy, D. A., W. J. Burke, and M. S. Gussenhoven, DMSP optical and electron measurements in the vicinity of polar cap arcs, J. Geophys. Res., 87, 2413-2430, 1982.

Heelis, R. A., The effects of interplanetary magnetic field orientation on 
dayside high-latitude ionospheric convection, J. Geophys. Res., 89, 2873-2880, 1984.

Heelis, R. A., and W. B. Hanson, High-latitude ion convection in the nighttime $F$ region, J. Geophys. Res., 85, 1995-2002, 1980.

Heelis, R. A., W. B. Hanson, and J. L. Burch, Ion convection velocity reversals in the dayside cleft, J. Geophys. Res., 81, 3803-3809, 1976.

Heelis, R. A., J. K. Lowell, and R. W. Spiro, A model of the highlatitude ionospheric convection pattern, J. Geophys. Res., 87, 6339$6345,1982$.

Heppner, J. P., Polar cap electric field distributions related to the interplanetary magnetic field direction, J. Geophys. Res., 77, 48774887, 1972.

Heppner, J. P., Empirical models of high-latitude electric fields, $J$. Geophys. Res., 82, 1115-1125, 1977.

Iijima, T., T. A. Potemra, L. J. Zanetti, and P. F. Bythrow, Large-scale Birkeland currents in the dayside polar region during strongly northward IMF: A new Birkeland current system, J. Geophys. Res., 89, 7441-7452, 1984.

Ismail, S., and C.-I. Meng, A classification of polar cap auroral arcs, Planet. Space Sci., 30, 319-330, 1982.

Kelley, M. C., G. Haerendel, H. Kappler, F. S. Mozer, and U. V. Fahleson, Electric field measurements in a major magnetospheric substorm, J. Geophys. Res., 80, 3181-3195, 1975.

Killeen, T. L., R. A. Heelis, P. B. Hays, N. W. Spencer, and W. B. Hanson, Neutral motions in the polar thermosphere for northward interplanetary magnetic field, Geophys. Res. Lett., 12, 159-162, 1985.

Knudsen, W. C., P. M. Banks, J. D. Winningham, and D. M. Klumpar, Numerical model of the convecting $F_{2}$ ionosphere at high latitudes, $J$. Geophys. Res., 82, 4784-4792, 1977.

Maezawa, K., Magnetospheric convection induced by the positive and negative $z$ components of the interplanetary magnetic field: Quantitative analysis using polar cap magnetic records, J. Geophys. Res., 81, 2289-2303, 1976.

Maynard, N. C., Electric field measurements across the Harang discontinuity, J. Geophys. Res., 79, 4620-4631, 1974.

Mozer, F. S., and P. Lucht, The average auroral zone electric field, $J$. Geophys. Res., 79, 1001-1006, 1974.

Quegan, S., G. J. Bailey, R. J. Moffet, R. A. Heelis, T. J. Fuller-Rowell, D. Rees, and R.W. Spiro, A theoretical study of the distribution of ionization in the high-latitude ionosphere and the plasmasphere: First results on the mid-latitude trough and the light-ion trough, $J$. Atmos. Terr. Phys., 44, 619-640, 1982.

Rasmussen, C. E., R. W. Schunk, and J. J. Sojka, Effects of different convection models upon the high-latitude ionosphere, J. Geophys. Res., 91, 6999-7005, 1986.

Reiff, P. H., Sunward convection in both polar caps, J. Geophys. Res., $87,5976-5980,1982$.

Schunk, R. W., and W. J. Raitt, Atomic nitrogen and oxygen ions in the daytime high-latitude $F$ region, J. Geophys. Res., 85, 1255-1272, 1980.

Schunk, R. W., and J. J. Sojka, Ion temperature variations in the daytime high-latitude $F$ region, $J$. Geophys. Res., 87, 5169-5183, $1982 a$.

Schunk, R. W., and J. J. Sojka, Ionospheric hot spots at high latitudes, Geophys. Res. Lett., 9, 1045-1048, $1982 b$.
Schunk, R. W., and J. C. G. Walker, Theoretical ion densities in the lower ionosphere, Planet. Space Sci., 21, 1875-1896, 1973.

Schunk, R. W., W. J. Raitt, and P. M. Banks, Effect of electric fields on the daytime high-latitude $E$ and $F$ regions, J. Geophys. Res., 80, 3121-3130, 1975.

Schunk, R. W., P. M. Banks, and W. J. Raitt, Effects of electric fields and other processes upon the nighttime high latitude $F$ layer, $J$. Geophys. Res., 81, 3271-3282, 1976.

Schunk, R. W., J. J. Sojka, and M. D. Bowline, Theoretical study of the electron temperature in the high-latitude ionosphere for solar maximum and winter conditions, J. Geophys. Res., 91, 12,041-12,054, 1986.

Sojka, J. J., and R. W. Schunk, A theoretical study of the high latitude $F$ region's response to magnetospheric storm inputs, J. Geophys. Res., 88, 2112-2122, 1983.

Sojka, J. J., and R. W. Schunk, A theoretical $F$ region study of ion compositional and temperature variations in response to magnetospheric storm inputs, J. Geophys. Res., 89, 2348-2358, 1984.

Sojka, J. J., and R. W. Schunk, A theoretical study of the global $F$ region for June solstice, solar maximum, and low magnetic activity, J. Geophys. Res., 90, 5285-5298, 1985.

Sojka, J. J., W. J. Raitt, and R. W. Schunk, A theoretical study of the high-latitude winter $F$ region at solar minimum for low magnetic activity, J. Geophys. Res., 86, 609-621, 1981a.

Sojka, J. J., W. J. Raitt, and R. W. Schunk, Theoretical predictions for ion composition in the high-latitude winter $F$ region for solar minimum and low magnetic activity, J. Geophys. Res., 86, 2206-2216, $1981 b$.

Sojka, J. J., R. W. Schunk, and W. J. Raitt, Seasonal variations of the high-latitude $F$ region for strong convection, J. Geophys. Res., 87, $187-198,1982$.

Sojka, J. J., C. E. Rasmussen, and R. W. Schunk, An interplanetary magnetic field dependent model of the ionospheric convection electric field, J. Geophys. Res., 91, 11,281-11,290, 1986.

Spiro, R. W., R. A. Heelis, and W. B. Hanson, Ion convection and the formation of the mid-latitude $F$ region ionization trough, $J$. Geophys. Res., 83, 4255-4264, 1978.

Spiro, R. W., P. H. Reiff, and L. J. Maher, Precipitation electron energy flux and auroral zone conductances-An empirical model, $J$. Geophys. Res., 87, 8125-8227, 1982.

Volland, H., Models of global electric fields within the magnetosphere, Ann. Geophys., 31, 154-174, 1975.

Volland, H., A model of the magnetospheric electric convection field, $J$. Geophys. Res., 83, 2695-2699, 1978.

Wallace, D. D., and E. E. Budzinski, Empirical models of height integrated conductivities, J. Geophys. Res., 86, 125-137, 1981.

Watkins, B. J., A numerical computer investigation of the polar $F$ region ionosphere, Planet. Space Sci., 26, 559-569, 1978.

R. W. Schunk and J. J. Sojka, Center for Atmospheric and Space Sciences, UMC 4405, Utah State University, Logan, UT, 84322.

(Received November 4, 1986;

revised April 20, 1987;

accepted April 27, 1987.) 